\title{
Spatial variation in the structural parameters of Cymodocea nodosa seagrass meadows in the Canary Islands: a multiscaled approach
}

\author{
Carmen Barberá1,*, Fernando Tuya1, Arturo \\ Boyra', Pablo Sanchez-Jerez², Ivan Blanch' \\ and Ricardo J. Haroun' \\ 1 Dpto. Biología, Universidad de Las Palmas, Campus \\ de Tafira s/n, 35017 Las Palmas de Gran Canaria, \\ Canary Islands, Spain, e-mail: carmelebc@yahoo.es \\ 2 Unidad de Biología Marina, Dpto. Ciencias del Mar y \\ Biología Aplicada, Ap. 99, E-03080 Universidad de \\ Alicante, Alicante, Spain \\ ${ }^{*}$ Corresponding author
}

\begin{abstract}
Meadows of the seagrass Cymodocea nodosa (legislated as an endangered species) are the dominant vegetated communities in shallow soft bottoms throughout the Canary Islands (central east Atlantic Ocean). We provide baseline ecological information for this key species for the whole Canarian Archipelago by describing the spatial distribution patterns of structural parameters (percent coverage and shoot density) at different hierarchical spatial scales (from tens of meters to hundreds of kilometers). The coverage values varied between 42.5 and $100 \%$ (mean $\pm \mathrm{SE}=76.7 \pm 2.5 \%, \mathrm{~N}=80$ ) and the mean shoot density per location ranged between 164 and 710 shoots $\mathrm{m}^{-2}$ (mean $\pm \mathrm{SE}=403.6 \pm 17.0$ shoots $\mathrm{m}^{-2}, \mathrm{~N}=160$ ). We observed a strong variability at small- to mediumspatial scales (locations within islands separated by tens of kilometres and sites hundreds of meters apart within locations) in contrast to a lack of inter-island variability. Additionally, the structural parameters respond differentially to different sets of ecological and physical processes operating at these scales.
\end{abstract}

Keywords: Canarian Archipelago; Cymodocea nodosa; meadow structure; seagrass.

\section{Introduction}

The importance of seagrass meadows in coastal marine environments is related chiefly to their worldwide contribution to ocean productivity [estimated at $12 \%$ of the total net production (Duarte and Cebrián 1996)]. Seagrasses perform several important ecological and physical functions (see Hemminga and Duarte 2000, Short et al. 2001 for reviews), such as: (1) aiding sediment stability, (2) in situ generation of detritus, (3) providing a net source of nutrients, (4) increasing the heterogeneity of the seascape, and therefore the diversity and abundance of species, and (5) channelling primary production to high trophic levels. Consequently, seagrass meadows are considered one of the most valuable ecosystems in terms of the value-added benefits of the functions they provide (Duarte and Cebrián 1996, Short and WyllieEcheverria 1996, Hemminga and Duarte 2000).

However, recently published reports point to an increase in the stress and decline of seagrass meadows, especially in areas of intense human disturbances (Short and Wyllie-Echeverria 1996, Short et al. 2001), such as large urban and industrial coastal zones (Larkum and West 1983, Shepherd et al. 1989). Documenting changes in seagrass patterns is therefore a priority in the assessment of nearshore ecosystem health (Dennison et al. 1993). Descriptors of the spatial structure of seagrass meadows are excellent indicators for determining degree of development, quality and state of health, as well as a way for assessing the effects of disturbances and impacts from various sources (West 1990, Garcia-Charton et al. 1993, Marcos-Diego et al. 2000, Ruiz 2000, 2001).

Marine assemblages respond to changes in the environmental conditions of the coastal ocean with spatiotemporal fluctuations operating at various scales of observation. A major goal in ecology is to understand the ecological nature of the natural and/or anthropogenic processes involved in this variability. In this sense, hierarchically structured sampling designs provide a means of partitioning and quantifying the magnitude of variation at different scales (Underwood 1997, Kingsford and Battershill 1998).

Meadows of the seagrass Cymodocea nodosa (Ucria) Ascherson are the dominant vegetated communities in shallow soft substrates throughout the Canary Islands (central east Atlantic Ocean). These meadows are generally located along the eastern and southern coasts of the islands, forming extensive subtidal meadows (Reyes et al. 1995a, Pavón-Salas et al. 2000). In some locations, Cymodocea nodosa meadows are mixed with species of the green alga Caulerpa (Pavón-Salas et al. 2000). Seagrass meadows are considered as a habitat in decline throughout the Canarian coastal areas, and hence Cymodocea nodosa is legislated as an endangered species (Decreto 151/2001, de 23 de Julio, Catálogo de Especies Amenazadas de Canarias). However, there are only few studies on the spatial structure of this species at several locations of the Canarian Archipelago (Reyes et al. 1995a,b, Reyes and Sansón 1997 at El Medano, Tenerife island; and Tuya et al. 2002 at Playa Blanca, Lanzarote island). Hence, the general aim of our study was to describe the spatial variability of structural descriptors of Cymodocea nodosa seagrass meadows through a multiscaled perspective to provide baseline information datasets for management and conservation proposals throughout coastal areas of the Canary Islands. 


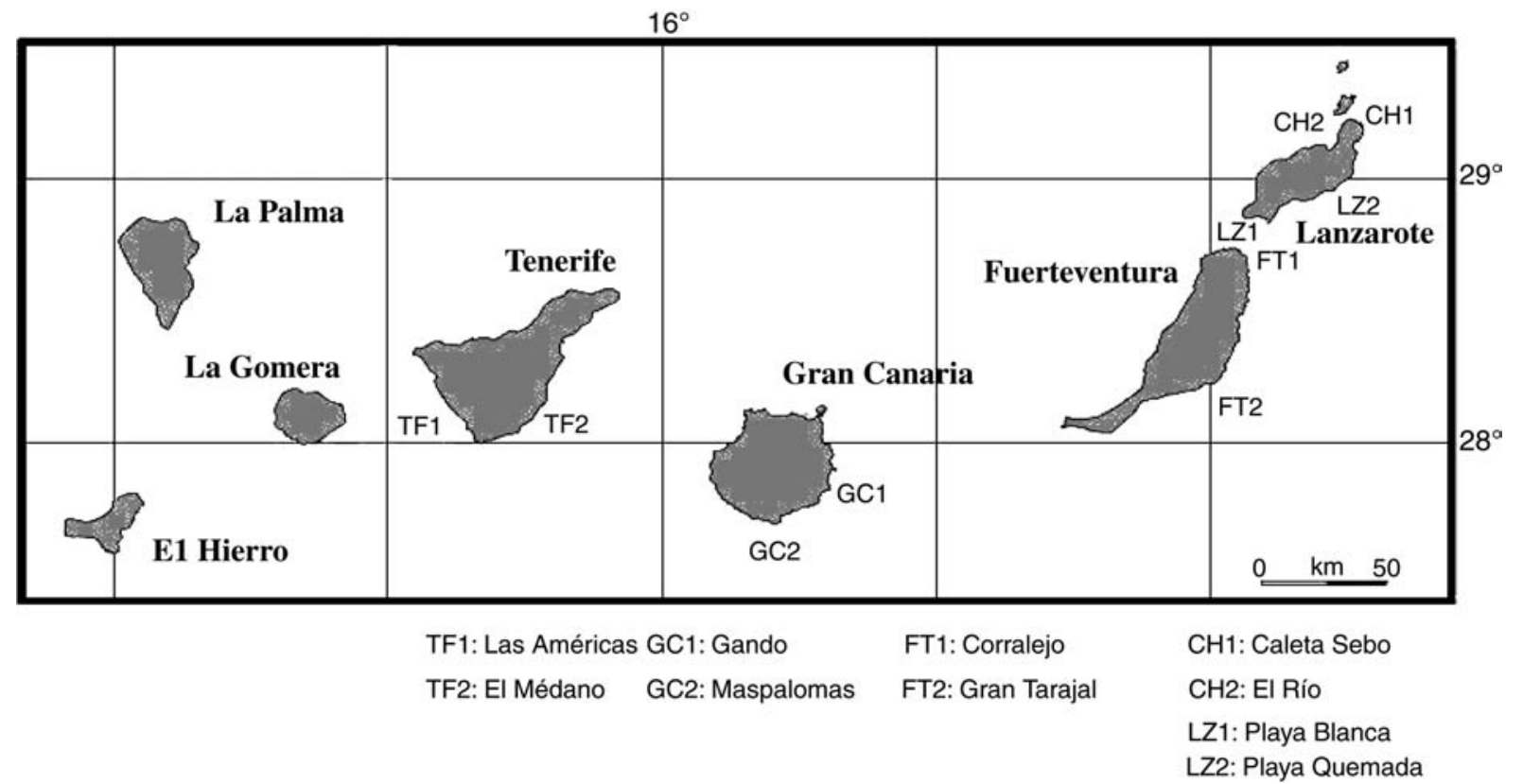

Figure 1 Map of the Canarian Archipelago showing sampling locations on each island.

\section{Materials and methods}

We selected non-destructive sampling techniques to assess the following structural descriptors of seagrass meadows: (1) coverage (\%) and (2) shoot density (shoots $\left.\mathrm{m}^{-2}\right)$. Both were estimated according to standardized procedures (Panayotidis et al. 1981, Romero 1985, Larkum et al. 1989, Hemminga and Duarte 2000, Short et al. 2001).

Coverage was sampled with $1 \mathrm{~cm} \times 25 \mathrm{~m}$ flexible line transects. Surface distance under the transect covered by the seagrass Cymodocea nodosa and different algal species was measured to the nearest $\mathrm{cm}$ and percent cover calculated. Two random points were chosen within living seagrass patches along transects to estimate in situ by means of $25 \times 25 \mathrm{~cm}$ quadrats $(n=8)$ the number of Cymodocea nodosa shoots.

A hierarchical (nested) sampling design was chosen to estimate the variation of seagrass meadows descriptors at different spatial scales, from tens of meters among replicate transects to hundreds of kilometres among islands (Underwood 1997, Kingsford and Battershill 1998). Our sampling design incorporated the five islands where seagrass meadows have been observed among the Canary Islands (Tenerife, Gran Canaria, Fuerteventura, Lanzarote and Chinijo Archipelago; Pavón-Salas et al. 2000; Figure 1). Two locations, separated by tens of kilometres, and inhabited by shallow seagrass stands on soft bottoms (12-18 $\mathrm{m}$ deep) were randomly selected at each of the five islands. Two sites, separated by hundreds of meters, were additionally sampled within each location. Finally, four $25 \mathrm{~m}$-long transects situated tens of meters apart within each site were haphazardly deployed. Seasonality was not incorporated in the model as sampling was carried out from February to March 2003.

Nested ANOVA models were used to test the null hypothesis that the structural descriptors of meadows were similar across islands, locations within islands, and sites within locations. The model therefore considered three factors: (1) "islands" (fixed factor with five levels), (2) "locations" (random factor nested within islands with two levels) and (3) "sites" (random factor nested within locations and islands, with two levels: sites A and B). Before analysis, Cochran's test was used to check for homogeneity of variances. Since no transformation rendered homogeneous variances, the significant level was set at the 0.01 level instead of 0.05 , as ANOVA is robust to heterogeneity of variances, particularly for large balanced experiments (Underwood 1997).

\section{Results}

The two selected structural parameters of the seagrass Cymodocea nodosa responded differently to the three spatial scales considered by our sampling design. The mean coverage overall was $76.7 \pm 2.5 \%$ (Table 1, Figure 2). The coverage of Cymodocea nodosa was relatively homogeneous for the greatest spatial scale considered by our study: islands across the Canarian Archipelago, with no statistical differences among them (Table 2). On the other hand, our model detected statistical differences between surveyed locations (=meadows) within islands (Figure 2, Table 2). At the level of sites, statistical differences were also not found (Table 2). Three locations (GC1, Gando; GC2, Maspalomas; and TF1, Las Américas) displayed a large coverage of the green alga Caulerpa prolifera. In addition, Caulerpa racemosa was recorded with a percent coverage $>1.0$ at LZ1 (Playa Blanca) and LZ2 (Playa Quemada) (Table 1).

Shoot density of Cymodocea nodosa seagrass meadows was also similar among islands (Table 2, Figure 2). Mean shoot density was $403.6 \pm 17.0$ shoots $\mathrm{m}^{-2}$ (Table 1 ) over all samples, ranging between 164 to 710 shoots $\mathrm{m}^{-2}$ (Table 1). Locations and sites showed statistical differences (Table 2), which therefore reflect a clear heterogeneity in this parameter within each island (Table 1). 
Table 1 Structural parameters (mean \pm SE) of the Cymodocea nodosa meadows at sampling locations (Figure 1) in the Canary Islands.

\begin{tabular}{|c|c|c|c|c|c|c|c|c|}
\hline \multirow[t]{2}{*}{ Island } & \multirow[t]{2}{*}{ Location } & \multirow[t]{2}{*}{ Site } & \multicolumn{5}{|c|}{$\%$ Coverage $(n=4)$} & \multirow{2}{*}{$\begin{array}{l}\text { Shoot density } \\
\left(\text { shoots } \mathrm{m}^{-2}\right)(\mathrm{n}=8)\end{array}$} \\
\hline & & & $\begin{array}{l}\text { Cymodocea } \\
\text { nodosa }\end{array}$ & $\begin{array}{l}\text { Mixed C. nodosa/ } \\
\text { C. prolifera }\end{array}$ & $\begin{array}{l}\text { Caulerpa } \\
\text { prolifera }\end{array}$ & $\begin{array}{l}\text { Caulerpa } \\
\text { racemosa }\end{array}$ & $\begin{array}{l}\text { Other } \\
\text { algae }\end{array}$ & \\
\hline \multirow[t]{4}{*}{ Chinijo Archipelago } & $\mathrm{CH} 1$ & A & $99.5 \pm 0.5$ & - & $<1$ & - & - & $710.0 \pm 64.3$ \\
\hline & & B & $90.0 \pm 2.0$ & - & $5.0 \pm 2.0$ & - & - & $592.0 \pm 53.7$ \\
\hline & $\mathrm{CH} 2$ & A & $66.2 \pm 14.3$ & - & - & $<1$ & - & $438.0 \pm 53.8$ \\
\hline & & B & $54.0 \pm 6.7$ & - & - & $<1$ & $18.0 \pm 9.0$ & $588.0 \pm 69.3$ \\
\hline \multirow{4}{*}{ Fuerteventura } & FT1 & A & $99.0 \pm 1.0$ & - & - & - & - & $230.0 \pm 32.3$ \\
\hline & & $B$ & $100.0 \pm 0.0$ & - & - & - & - & $260.0 \pm 33.1$ \\
\hline & FT2 & A & $84.7 \pm 10.4$ & - & $<1$ & - & - & $290.0 \pm 27.4$ \\
\hline & & $B$ & $80.0 \pm 10.8$ & - & $<1$ & - & - & $290.0 \pm 37.1$ \\
\hline \multirow[t]{4}{*}{ Gran Canaria } & GC1 & A & $46.2 \pm 3.1$ & $10.7 \pm 3.6$ & $2.5 \pm 1.3$ & - & - & $438.0 \pm 44.0$ \\
\hline & & B & $42.5 \pm 6.2$ & $12.3 \pm 3.7$ & $1.4 \pm 1.8$ & - & - & $276.0 \pm 33.6$ \\
\hline & GC2 & $A$ & $66.2 \pm 7.5$ & $20.3 \pm 8.4$ & $3.5 \pm 2.1$ & - & - & $180.0 \pm 27.3$ \\
\hline & & B & $77.5 \pm 8.2$ & $15.1 \pm 5.0$ & $2.4 \pm 1.1$ & - & - & $164.0 \pm 15.0$ \\
\hline \multirow[t]{4}{*}{ Lanzarote } & LZ1 & A & $95.0 \pm 5.0$ & - & - & $5.0 \pm 5.0$ & - & $584.0 \pm 54.0$ \\
\hline & & B & $94.2 \pm 4.8$ & - & - & $0.3 \pm 0.3$ & - & $692.0 \pm 60.3$ \\
\hline & LZ2 & $A$ & $94.0 \pm 3.8$ & - & - & - & - & $384.0 \pm 26.2$ \\
\hline & & B & $76.2 \pm 18.8$ & - & - & $1.2 \pm 1.2$ & - & $282.0 \pm 24.9$ \\
\hline \multirow[t]{4}{*}{ Tenerife } & TF1 & A & $73.7 \pm 9.4$ & - & $25.0 \pm 10.0$ & - & - & $241.6 \pm 57.6$ \\
\hline & & B & $62.7 \pm 14.4$ & - & $16.7 \pm 11.1$ & - & - & $249.6 \pm 25.6$ \\
\hline & TF2 & A & $67.7 \pm 4.1$ & - & - & - & - & $396.0 \pm 41.4$ \\
\hline & & B & $65.0 \pm 4.6$ & - & - & - & - & $479.0 \pm 41.9$ \\
\hline Total & & & $76.7 \pm 2.5$ & $3.7 \pm 1.3$ & $1.6 \pm 0.7$ & $2.1 \pm 1.0$ & $0.9 \pm 0.6$ & $403.6 \pm 17.0$ \\
\hline
\end{tabular}

\section{Discussion}

Hierarchical sampling designs are a first step in understanding different sources of processes that affect natural systems. Each source of spatial variation may thus represent a set of ecological processes. The spatial variability of Cymodocea nodosa seagrass systems throughout the Canarian Archipelago is important at scales ranging from hundreds of meters to tens of kilometres within islands, in contrast to a lack of variability among surveyed islands (hundreds of kilometres). This suggests that spatial variability associated with mesoscale oceanographic processes does not play a significant role in structuring the meadows.

Diverse factors can control the complexity and structure of Cymodocea nodosa seagrass meadows within islands at scales ranging from hundreds of meters to tens of kilometres. The structure of seagrass meadows is a function of the interplay between (1) environmental factors (e.g., light and nutrient availability, sediment characteristics, water turbulence) (Fonseca et al. 1983, Pérez and Romero 1992, Terrados and Ros 1992, 1993, Schanz and Asmus 2003), (2) biotic interactions (e.g., competition, grazing, presence of epiphytes) (Williams 1987) and (3) species-specific life history characteristics (e.g. physiology, etc.) (Tomasko 1992).

The shoot densities we recorded are of the same order of magnitude as those observed by other works across the Canary Islands (Reyes et al. 1995, Tuya et al. 2002). However, the range of variation (164-710 shoots $\left.\mathrm{m}^{-2}\right)$ is lower than those found in previous studies (1000-2000 shoots $\mathrm{m}^{-2}$, Reyes et al. 1995; 400-1000 shoots $\mathrm{m}^{-2}$, Tuya et al. 2002), as well as those reported from the Mediterranean Sea [1000-2000 shoots $\mathrm{m}^{-2}$ (Pérez 1989);

Table 2 Results of 3-way nested ANOVAs on the structural parameters of Cymodocea nosoda meadows throughout the Canarian Archipelago.

\begin{tabular}{|c|c|c|c|c|c|c|}
\hline \multicolumn{7}{|l|}{ Coverage } \\
\hline Sources of variation & Factor & df & MS versus & MS & F-ratio & $\mathrm{p}$ \\
\hline $\mid=$ Island & fixed & 4 & $\mathrm{~L}(\mathrm{l})$ & 3239.92 & 1.73 & 0.2795 \\
\hline$L(I)=$ Location $(I)$ & random, nested & 5 & Site $[L(I)]$ & 1873.74 & 11.04 & 0.0008 \\
\hline Site $[L(I)]$ & random, nested & 10 & Residual & 169.74 & 0.60 & 0.8056 \\
\hline Residual & & 60 & & 281.80 & & \\
\hline Total & & 79 & & & & \\
\hline \multicolumn{7}{|l|}{ Density } \\
\hline Sources of variation & Factor & df & MS versus & MS & F-ratio & $p$ \\
\hline $\mid=$ Island & fixed & 4 & $\mathrm{~L}(\mathrm{I})$ & 2477.09 & 2.19 & 0.2100 \\
\hline $\mathrm{L}(\mathrm{I})=$ Location $(\mathrm{I})$ & random, nested & 5 & Site $[\mathrm{L}(\mathrm{I})]$ & 1145.55 & 8.02 & 0.0000 \\
\hline Site $(L(I))$ & random, nested & 10 & Residual & 142.86 & 2.39 & 0.0100 \\
\hline Residual & & 140 & & 59.87 & & \\
\hline Total & & 159 & & & & \\
\hline
\end{tabular}



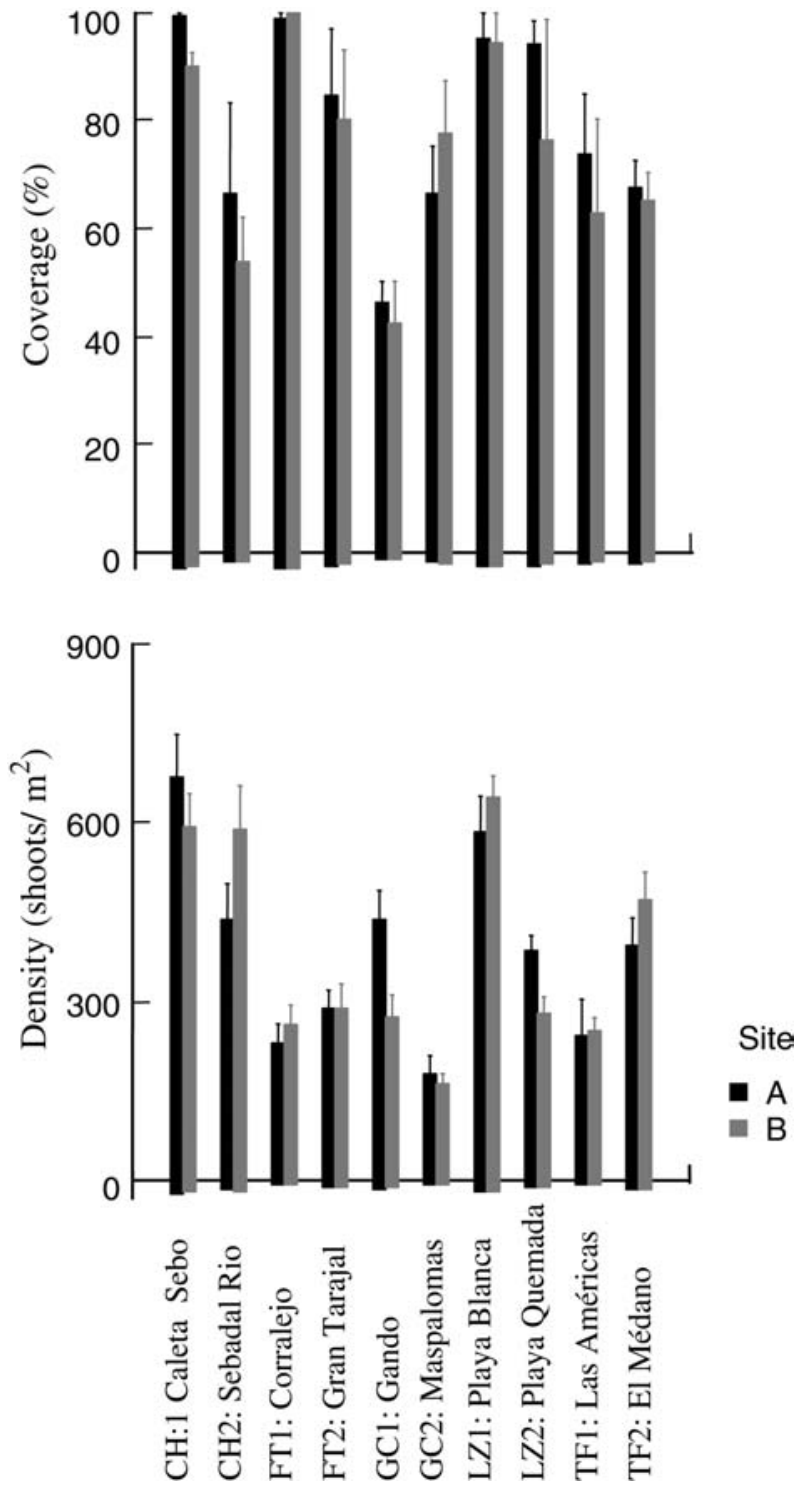

Figure 2 Coverage and shoot density of the Cymodocea nodosa seagrass meadows (mean $\pm \mathrm{SE}$ ) at the two sampling sites within each location surveyed.

1000-1900 shoots $\mathrm{m}^{-2}$ (Terrados and Ros 1992); 925-1925 shoots $\mathrm{m}^{-2}$ (Cancemi et al. 2002); 757-1520 shoots $\mathrm{m}^{-2}$ (Agostini et al. 2003)].

The mean percentage of Cymodocea nodosa coverage across seagrass meadows of the Canarian Archipelago $(76.7 \%)$ seems to be similar to those obtained in meadows of Tenerife (41-79\%) and in the Mediterranean Sea (68\%) (unpublished data, Ruiz personal communication). There were no differences in cover between sites, which might be a consequence of the low number of replicates within sites for this parameter $(n=4)$ in contrast to the number of replicates for density $(n=8)$. Consequently, the power to reject the null hypothesis through the ANOVAs is different for both parameters.

The fact that shoot density is lower than those found by other studies is likely attributable to seasonality, as our sampling was carried out only in winter. Nevertheless, the meadows are in regions of considerable human disturbance, and it is known that perturbations influence the structure and dynamics of this community (Tuya et al.
2002). Anthropogenic disturbance is often related to proliferation of Caulerpa species. This proliferation in disturbed sites may negatively affect Cymodocea nodosa density (Ceccherelli and Campo 2002). However, further surveys and an experimental approach are needed to test this proposition (Dethier 1984, Agawin et al. 1996).

Seagrass meadows such as those in the Canary Islands play an important role in the provision of habitat for faunal assemblages and, consequently, in the availability of trophic resources in littoral areas (SánchezJerez et al. 1999, Guidetti and Bussotti 2000, Boström and Bonsdorff 2000, Barberá et al. 2002). Degradation of the meadows could negatively affect the whole Canarian coastal ecosystem. Our study has shown that the parameters that describe the structure of seagrass meadows respond differently to different sets of ecological and physical processes. Hence, impact assessment studies should include in their sampling procedures the measurement of a wide set of structural parameters, as an effective way to detect possible impacts at different spatial scales on this valuable environment.

\section{Acknowledgements}

Research was economically supported by the Spanish "Ministerio de Medio Ambiente" in the framework of the "Canarias, por una costa viva" project (www.canariasporunacostaviva.org) in collaboration with WWF/Adena. We gratefully thank T. Sánchez, A. Iglesias, A. López, N. Rodriguez, A. Del Rosario, G. Herrera, $R$. Herrera and F. Espino for helping us with the underwater data collection. Corrections by Dr. J.M. Ruiz significantly improved the manuscript.

\section{References}

Agawin, N.S.R., C.M. Duarte and M.D. Fortes. 1996. Nutrient limitation of Philippine seagrasses (Cape Bolinao, NW Philippines): in situ experimental evidence. Mar. Ecol. Prog. Ser. 138: 233-243.

Agostini, S., G. Pergent and B. Marchand. 2003. Growth and primary production of Cymodocea nodosa in a coastal lagoon. Aquat. Bot. 76: 185-193.

Barberá, C., P. Sanchez-Jerez and A.A. Ramos Esplá. 2002. Fragmented seagrass habitats on the Mediterranean coast and distribution and abundance of mysid assemblages. Mar. Biol. 141: 405-413.

Boström, C. and E. Bonsdorff. 2000. Zoobenthic community establishment and habitat complexity - the importance of seagrass shoot-density, morphology and physical disturbance for faunal recruitment. Mar. Ecol. Prog. Ser. 205: 123-138.

Cancemi, G., M.C. Buia and L. Mazzella. 2002. Structure and growth dynamics of Cymodocea nodosa meadows. Sci. Mar. 66: 365-373.

Ceccherelli, G. and D. Campo. 2002. Different effects of Caulerpa racemosa on two co-occurring seagrasses in the Mediterranean. Bot. Mar. 45: 71-76.

Dennison, W.C., R.J. Orth, K.A. Moore, J.C. Stevenson and V. Carter. 1993. Assessing water quality with submersed aquatic vegetation. BioScience 43: 86-94.

Dethier, M.N. 1984. Disturbance and recovery in intertidal pools: maintenance of mosaic patterns. Ecol. Monogr. 54: 99-118.

Duarte, C.M. and J. Cebrián. 1996. The fate of marine autotrophic production. Aquat. Bot. 41: 1758-1766. 
Fonseca, M.S., J.C. Zieman, G.W. Thayer and J.S. Fisher. 1983. The role of current velocity in structuring eelgrass (Zostera marina L.) meadows. Estuar. Coast. Shelf Sci. 17: 367-380.

García-Charton, J.A., J. Bayle-Sempere, J.L. Sanchez-Lizaso, P. Chiesa, F. Llaurado, C. Perez and H. Djian. Respuesta de la pradera de Posidonia oceanica y su ichtyofauna asociada al anclaje de embarcaciones en el Parque Nacional de PortCros (Francia). Publ. Esp. Inst. Esp. Ocean. 11: 423-430.

Guidetti, P. and S. Bussotti. 2000. Fish fauna of a mixed meadow composed by the seagrasses Cymodocea nodosa and Zostera noltii in the Western Mediterranean. Oceanol. Acta. 23: 759-770.

Hemminga, M.A. and C.M. Duarte. 2000. Seagrass ecology. Cambridge University Press. Cambridge. pp. 298.

Kingsford, M. and C. Battershill. 1998. Studying temperate marine environments: a handbook for ecologists. Canterbury University Press. University of Canterbury. New Zealand. pp. 335.

Larkum, A.W.D. and R.J. West. 1983. Stability, depletion and restoration of seagrass beds. Proc. Linn. Soc. NSW 106: 201-202.

Larkum, A.W.D., A.J. McComb and S.A. Shepherd. 1989. Biology of seagrasses. A treatise on the biology of seagrasses with special references to the Australian region. Elsevier Science, Amsterdam. pp. 841.

Marcos-Diego, C., G. Bernard, J.A. García-Charton and A. Pérez-Ruzafa. 2000. Methods for studying impact on Posidonia oceanica meadows. In: (R. Goñi, M. Harmelin-Vivien, F. Badalamenti, L. Le Diréach and G. Bernard, eds) Introductory guide to methods for selected ecological studies in marine reserves. GIS Posidonie publications, Marseille. pp. 57-62.

Panayotidis, P., C.F. Boudouresque and J. Marcot-Coqueugniot. 1981. Microstructure de l'herbier de Posidonia oceanica (Linnaeus) Delile. Bot. Mar. 24: 115-124.

Pavón-Salas, N., R. Herrera, A. Hernández-Guerra and R.J. Haroun. 2000. Distributional pattern of seagrasses in the Canary Islands (Central-East Atlantic Ocean). J. Coast. Res. 16: 329-335.

Pérez, M. 1989. Fanerógamas marinas en sistemas estuáricos: producción, factores limitantes y algunos aspectos del ciclo de nutrientes. Tesis doctoral. Universidad de Barcelona. pp. 244.

Pérez, M. and J. Romero. 1992. Photosynthetic response to light and temperature of the seagrass Cymodocea nodosa and the prediction of its seasonality. Aquat. Bot. 43: 51-62.

Reyes, J. and M. Sansón. 1997. Temporal distribution and reproductive phenology of the epiphytes on Cymodocea nodosa leaves in the Canary Islands. Bot. Mar. 40: 193-201.

Reyes, J., M. Sansón and J.A. Carrillo. 1995a. Leaf phenology, growth and production of the seagrass Cymodocea nodosa at El Médano (South of Tenerife, Canary Islands). Bot. Mar. 38: 457-465.

Reyes, J., M. Sansón and J.A. Afonso-Carrillo. 1995b. Distribution and reproductive phenology of the seagrass Cymo- docea nodosa (Ucria) Ascherson in the Canary Islands. Aquat. Bot. 50: 171-180.

Romero, J. 1985. Estudio ecológico de las fanerógamas marinas de la costa catalana: producción primaria de Posidonia oceanica (L.) Delile, en las Islas Medes. Tesis doctoral. Universidad de Barcelona. pp. 266.

Ruiz, J.M. 2000. Respuesta de la fanerógama marina Posidonia oceanica (L.) Delile a perturbaciones antrópicas. Tesis Doctoral. Universidad de Murcia. pp. 212.

Ruiz, J.M. 2001. Effects of fish farm loadings on seagrass (Posidonia oceanica) distribution, growth and photosynthesis. Mar. Pollut. Bull. 42: 749-760.

Sanchez-Jerez, P., C. Barberá and A.A. Ramos Esplá. 1999. Comparison of the epifauna spatial distribution in Posidonia oceanica, Cymodocea nodosa and unvegetated bottoms: importance of meadow edges. Acta Oecol. 20: 391-405.

Schanz, A. and H. Asmus. 2003. Impact of hydrodynamics on development and morphology of intertidal seagrasses in the Wadden Sea. Mar. Ecol. Prog. Ser. 261: 123-134.

Shepherd, S.A., A.J. Mc Comb, D.A. Bulthuis, V. Neverauskas, D.A. Steffensen and R. West, 1989. Decline of seagrasses. In: (A.W.D. Larkum, A.J. Mc Comb and S.A. Shepherd, eds) Biology of seagrass. Aquatic plant studies. Vol. 2. Elsevier Science, Amsterdam. pp. 346-393.

Short, F.T. and S. Wyllie-Echeverria. 1996. Natural and humaninduced disturbances of seagrass. Environ. Conserv. 23: $17-27$.

Short, F.T., R.G. Coles and C. Pergent-Martini. 2001. Global seagrass distribution. In: (F.T. Short and R.G. Coles, eds) Global seagrass research methods. Elsevier Science, Amsterdam. pp. 5-30.

Terrados, J. and J.D. Ros. 1992. Growth and primary production of Cymodocea nodosa (Ucria) Ascherson in a Mediterranean coastal lagoon: the Mar Menor (SE Spain). Aquat. Bot. 43: 63-74.

Terrados, J. and J.D. Ros. 1993. Limitación por nutrientes de crecimiento de Cymodoceca nodosa (Curia) Ascherson en sedimentos carbonatados en el Mar Menor, Murcia, SE de España. Publ. Espec. Inst. Esp. Oceanogr. 11: 9-14.

Tomasko, D.A. 1992. Variation in growth form of shoal grass (Halodule wrightii) due to changes in the spectral composition of light below a canopy of turtle grass (Thalassia testudinum). Estuaries 15: 214-217.

Tuya, F., J.A. Martín and A. Luque. 2002. Impact of a marina construction on a seagrass bed at Lanzarote (Canary Islands). J. Coast. Conserv. 8: 157-162.

Underwood, A.J. 1997. Experiments in ecology: their logical design and interpretation using analysis of variance. Cambridge University Press, Cambridge. pp. 504.

West, R.J. 1990. Depth-related structural and morphological variations in an Australian Posidonia seagrass bed. Aquat. Bot. 36: 153-166.

Williams, S.L. 1987. Competition between the seagrass Thalassia testudinum and Syringodium filiforme in a Caribbean lagoon. Mar. Ecol. Prog. Ser. 35: 91-98.

Received 18 August, 2004; accepted 15 February, 2005 